\title{
Diet influence on egg production of the copepod Acartia tonsa (Dana, 1896)
}

\author{
PRISCILA F. TEIXEIRA ${ }^{1}$, SONIA M. KAMINSKI ${ }^{1}$, TATIANA R. AVILA ${ }^{1}$, \\ ALESSANDRO P. CARDOZO ${ }^{2}$, JOSÉ G.F. BERSANO ${ }^{3}$ and ADALTO BIANCHINI ${ }^{4}$ \\ ${ }^{1}$ Universidade Federal do Rio Grande, FURG, Instituto de Oceanografia, Laboratório de Zooplâncton \\ Av. Itália, km 8, 96201-900 Rio Grande, RS, Brasil \\ ${ }^{2}$ Universidade Federal do Rio Grande, FURG, Instituto de Oceanografia \\ Laboratório de Ecologia de Fitoplâncton e Microorganismos Marinhos, Av. Itália, km 8, 96201-900 Rio Grande, RS, Brasil \\ ${ }^{3}$ Universidade Federal do Paraná, UFPR, Centro de Estudos do Mar, Av. Beira Mar s/n \\ Caixa Postal 50002, 83255-000 Pontal do Paraná, PR, Brasil \\ ${ }^{4}$ Universidade Federal do Rio Grande, FURG, Instituto de Ciências Biológicas, Laboratório de Zoofisiologia \\ Av. Itália, km 8, 96201-900 Rio Grande, RS, Brasil
}

Manuscript received on January 22, 2009; accepted for publication on August 4, 2009

\begin{abstract}
Egg production in the copepod Acartia tonsa was evaluated using different densities of the microalgae Thalassiosira weissflogii, Chaetoceros muelleri and Isochrysis galbana. Male and female were kept under controlled conditions (salinity $30,20^{\circ} \mathrm{C}$, photoperiod $12 \mathrm{~L}: 12 \mathrm{D}$ ), acclimated to the experimental conditions and left over a period of $24 \mathrm{~h}$ to allow copulation. Algal densities tested were equivalent in biovolume and corresponded to 0, 2.5, 5, 10, 20, 40 and $60.10^{3}$ cells. $\mathrm{mL}^{-1}$ of $T$. weissflogii. Ten acclimated female were separated, transferred to glass bottles and exposed for further $24 \mathrm{~h}$ to the corresponding experimental medium. After this period, the eggs were fixed and counted. Copepod egg production reached a threshold value when T. weissflogii, C. muelleri and I. galbana were supplied at $10.10^{3}$, $140.10^{3}$ and $640.10^{3}$ cells. $\mathrm{mL}^{-1}$, respectively. Mean egg production corresponded to $28.0 \pm 0.5,20.1 \pm 1.0$ and $22.0 \pm 3.5$ eggs.female ${ }^{-1}$.day $^{-1}$, respectively. Copepods fed T. weissflogii showed the highest mean egg production while those fed I. galbana reached a maximum egg production when the algae were supplied at a density two- to fourfold higher, considering the biovolume of $T$. weissflogii and $C$. muelleri. These differences are explained considering the different sizes of the microalgae used to feed the copepods.
\end{abstract}

Key words: egg production, Acartia tonsa, microalgae.

\section{INTRODUCTION}

Copepods from the genus Acartia play an important role in the food webs of estuaries in both tropical and subtropical areas (Björnberg 1981, Mauchline 1998). Generally, they show the higher biomass values in most shallow enclosed bays and estuaries (Azaiteiro et al. 2005, Leandro et al. 2007). This fact may be related to their omnivorous feeding behavior, being able to survive and reproduce under different diets (Kleppel 1992, Saiz et al.

Correspondence to: Tatiana Ramos Avila

E-mail: tatioceano@yahoo.com.br
2007). Such characteristic makes Acartia species relatively easy to cultivate at small- and large-scale under laboratory conditions, providing enough biomass for use as an alternative live food in marine aquaculture (Støttrup and Nosker 1997, McKinnon et al. 2003) and a biological model in toxicological tests (Bielmyer et al. 2006, Pedroso et al. 2007, Pinho et al. 2007).

The increased use of copepods as live food in commercial fish hatcheries (Delbare et al. 1996, Schipp et al. 1999) can be explained by the use of different developmental stages of copepods as food source for fish 
of different sizes. The high nutritional value of copepods, which is characterized by a rich content in phospholipids, highly unsaturated fatty acids (HUFA), and natural antioxidants (Watanabe et al. 1983, Kraul et al. 1992, Sargent et al. 1997, Støttrup and Nosker 1997, Støttrup 2000, Helland et al. 2003), can also explain their actual broad use in aquaculture.

The success of a copepod culture depends on survival and fecundity rates of the cultivated animals, which are limited by food availability (Checkley 1980), temperature (Gaudy et al. 2000), and water salinity (Cardozo 2004). Egg production estimation is commonly used as an indicator of the nutritional quality of the food employed to feed the cultivated copepods (Butler and Dam 1994, Ceballos and Ianora 2003). Also, some studies have been performed to characterize the influence of different natural diets on copepod growth and egg production (Jakobsen et al. 2005, Kaminski and Montú 2005). All the information generated from these studies is important to select feeding regimes in order to improve copepod culture in laboratory (Støttrup and Jensen 1990, Castro-Longoria 2003, Cardozo 2004).

In light of the above, the aim of the present study was to evaluate the influence of the source and amount of food available on egg production in the copepod $A$. tonsa, using three different species of marine microalgae at different densities.

\section{MATERIALS AND METHODS}

The marine microalgae Thalassiosira weissflogii (Ø $13.2 \mu \mathrm{m})$, Chaetoceros muelleri (Ø $7.3 \mu \mathrm{m})$ and Isochrysis galbana $(\varnothing 4.7 \mu \mathrm{m})$ were used in the present study as food source for copepods. They were grown in 5-L bottles, using the Guillard F/2 adapted method (Guillard and Ryther 1962).

Copepods used in the tests were isolated from field samples collected in the Patos Lagoon estuary (Rio Grande, RS, Southern Brazil) and kept under laboratory conditions for approximately 5 generations. The culture was carried out in non-toxic plastic tanks (70 L) containing saltwater (salinity 30). Tanks were kept in a experimental room with fixed temperature $\left(20 \pm 1^{\circ} \mathrm{C}\right)$ and photoperiod (12L:12D). Copepods were daily fed a mixture of the three cultivated microalgae. Food was supplied in excess.
For each feeding regime (food source and density) adult copepods (50 males and 50 females) were acclimated for $24 \mathrm{~h}$ in glass bottles ( $1 \mathrm{~L})$ containing filtered (1 $\mu \mathrm{m}$ ) saltwater (salinity 30 ) and the microalgae to be tested at the desired density. For each feeding regime, 6 different microalgae densities were tested, including one control condition where no food was added to the experimental medium. Therefore, 19 glass bottles were used, each one containing 100 copepods (50 males and 50 females). Bottles containing copepods and the experimental medium were kept under fixed temperature (20 $\pm 1^{\circ} \mathrm{C}$ ) and photoperiod (12L:12D) and gently aerated to prevent algae sedimentation.

Algae densities were selected based on the saturation curve of egg production for A. tonsa fed on Rhodomonas baltica (Kiørboe et al. 1985). These authors have shown that $A$. tonsa achieved a stabilization on egg production at $\sim 500 \mu \mathrm{g} \mathrm{C.L}{ }^{-1}$. Considering the amount of carbon and the volume of $R$. baltica, the equivalent in biovolume required to achieve $\sim 500 \mu \mathrm{g} \mathrm{C.L}{ }^{-1}$ would be $20.10^{3}, 280.10^{3}$ and $320.10^{3}$ cells. $\mathrm{mL}^{-1}$ for T. weissflogii, C. muelleri and I. galbana, respectively. The other 5 algae densities were selected to bracket that giving $\sim 500 \mu \mathrm{g} \mathrm{C.L}{ }^{-1}$ and were calculated based on the $T$. weissflogii densities (Table I), using the equivalent biovolume approach (Hillebrand et al. 1999).

TABLE I

\begin{tabular}{|c|c|c|}
\hline \multicolumn{3}{|c|}{$\begin{array}{l}\text { Algal densities used in the experiments to measur } \\
\text { egg production in the copepod } \text { Acartia tonsa. } \\
\text { Algae densities are equivalent in biovolume. }\end{array}$} \\
\hline \multicolumn{3}{|c|}{ Densities $\left(10^{3}\right.$ cells.ml $\left.{ }^{-1}\right)$} \\
\hline $\begin{array}{c}\text { Thalassiosira } \\
\text { weissflogii }\end{array}$ & $\begin{array}{c}\text { Chaetoceros } \\
\text { muelleri }\end{array}$ & $\begin{array}{c}\text { Isochrysis } \\
\text { galbana }\end{array}$ \\
\hline 0 & 0 & 0 \\
\hline 2.5 & 35 & 40 \\
\hline 5 & 70 & 80 \\
\hline 10 & 140 & 160 \\
\hline 20 & 280 & 320 \\
\hline 40 & 560 & 640 \\
\hline 60 & 840 & 960 \\
\hline
\end{tabular}

The first 24-h period of test was used to acclimate copepods to the feeding regime and allow them to copulate. After this period, 3 groups of 10 female copepods from each bottle (experimental condition) were ran- 
domly collected and transferred to $300-\mathrm{mL}$ glass bottles (10 female copepods per bottle) containing the corresponding experimental medium. Therefore, each experimental condition (food source and density) was tested in triplicate, totalizing 63 experimental units. Female copepods were then kept for a further $24 \mathrm{~h}$ under the same experimental conditions (feeding regime, salinity 30 , temperature $20 \pm 1^{\circ} \mathrm{C}$, and photoperiod 12L:12D). Experimental medium were gently aerated to prevent algae sedimentation. Every 4 h, bottles were carefully agitated to keep algae cells in suspension.

After the second 24-h period of test, the experimental medium from each bottle was filtered $(20-\mu \mathrm{m}$ mesh filter). Eggs retained in the filter were transferred to $20-\mathrm{mL}$ bottles, fixed in $4 \%$ formaldehyde solution, and counted in squared Petri dishes under a stereomicroscope. Egg production was expressed as eggs.female ${ }^{-1}$. day $^{-1}$, considering the number of living females after the 48-h period of test.

Data from each experimental condition were expressed as mean \pm standard error $(n=3)$. Considering the facts that food availability is a natural factor limiting $A$. tonsa egg production and that the relationship between egg production and food quantity measured as algal density follows a saturation curve (e.g. Berggreen et al. 1988), the maximum egg production for each microalgae was determined through non-linear regression analysis (exponential with saturation), using SigmaPlot 2001 for Windows version 7.0 (SPSS Inc., USA).

\section{RESULTS}

For the three microalgae species used, mean egg production rate was dependent on the density of food supplied to copepods (Fig. 1). Mean egg production in copepods fed on T. weissflogii, C. muelleri and I. galbana increased as the algae cell density increased, until reaching $10.10^{3}, 140.10^{3}$ and $640.10^{3}$ cells. $\mathrm{mL}^{-1}$, respectively. In all cases, egg production did not change at higher cell densities. In fact, data obtained fitted well to a saturation-type kinetic model, especially for $T$. weissflogii and $C$. muelleri, where very high regression coefficients were observed $\left(\mathrm{R}^{2}=0.99\right.$ and 0.95 , respectively). For I. galbana, a significant data regression to a saturation-type kinetic model was also obtained, but a lower regression coefficient was observed $\left(\mathrm{R}^{2}=0.85\right)$.
This lower $\mathrm{R}^{2}$ value would be associated with an apparent outlier mean value observed at the density of $160.10^{3}$ cells.ml ${ }^{-1}$ (Fig. 1).

Copepod egg production was also dependent on food source provided to animals tested (Fig. 1). Based on the data regression model employed, the maximum mean egg production obtained was $28.0 \pm 0.5,22.0 \pm$ 3.5 , and $20.1 \pm 1.0$ eggs.female ${ }^{-1}$.day ${ }^{-1}$ with $T$. weissflogii, I. galbana and C. muelleri.

\section{DISCUSSION}

Data from the present study shows an influence of the microalgae species and density on the egg production in the copepod Acartia tonsa. At low microalgae densities, a low egg production was observed for the three microalgae tested. This fact could be explained by a decreased efficiency of food capture at low microalgae densities, as observed in A. tonsa fed with T. weissflogii (Paffenhofer and Stearns 1988). At high microalgae densities, egg production became stable was obtained for the three microalgae tested. Considering the equivalent biovolume approach (Hillebrand et al. 1999), density of $T$. weissflogii and C. muelleri showing stabilization in egg production corresponded to half of that using Rhodomonas baltica $\left(\sim 500 \mu \mathrm{g} \mathrm{C.L^{-1 }}\right)$. On the other hand, it corresponded to double for I. galbana (Kiørboe et al. 1985). These findings suggest that different carbon concentrations are required to obtain stabilization in egg production in A. tonsa when different food sources are employed.

For the three microalgae species, mean values of saturation in egg production (20 to 28 eggs.female ${ }^{-1}$. day $^{-1}$ ) were always higher than those measured in the field ( 1 to 16 eggs.female ${ }^{-1}$.day $^{-1}$ ) for $A$. tonsa (Kleppel et al. 1998, Kleppel and Hazzard 2000). For copepods fed on the same algae (T. weissflogii) under controlled conditions, the mean value observed for $A$. tons $a$ in the present study ( 28 eggs.female ${ }^{-1}$. day ${ }^{-1}$ ) was slightly higher than that reported for $A$. clausi (21 to 26 eggs. female ${ }^{-1}$.day $^{-1}$ ) by Richardson and Verheye (1998).

$A$. tonsa showed a higher egg production when fed on $T$. weissflogii than on C. muelleri or I. galbana. In turn, maximum egg production with I. galbana was similar to that with C. muelleri. However, a two- to four-fold higher biovolume (or amount of carbon) of I. galbana 


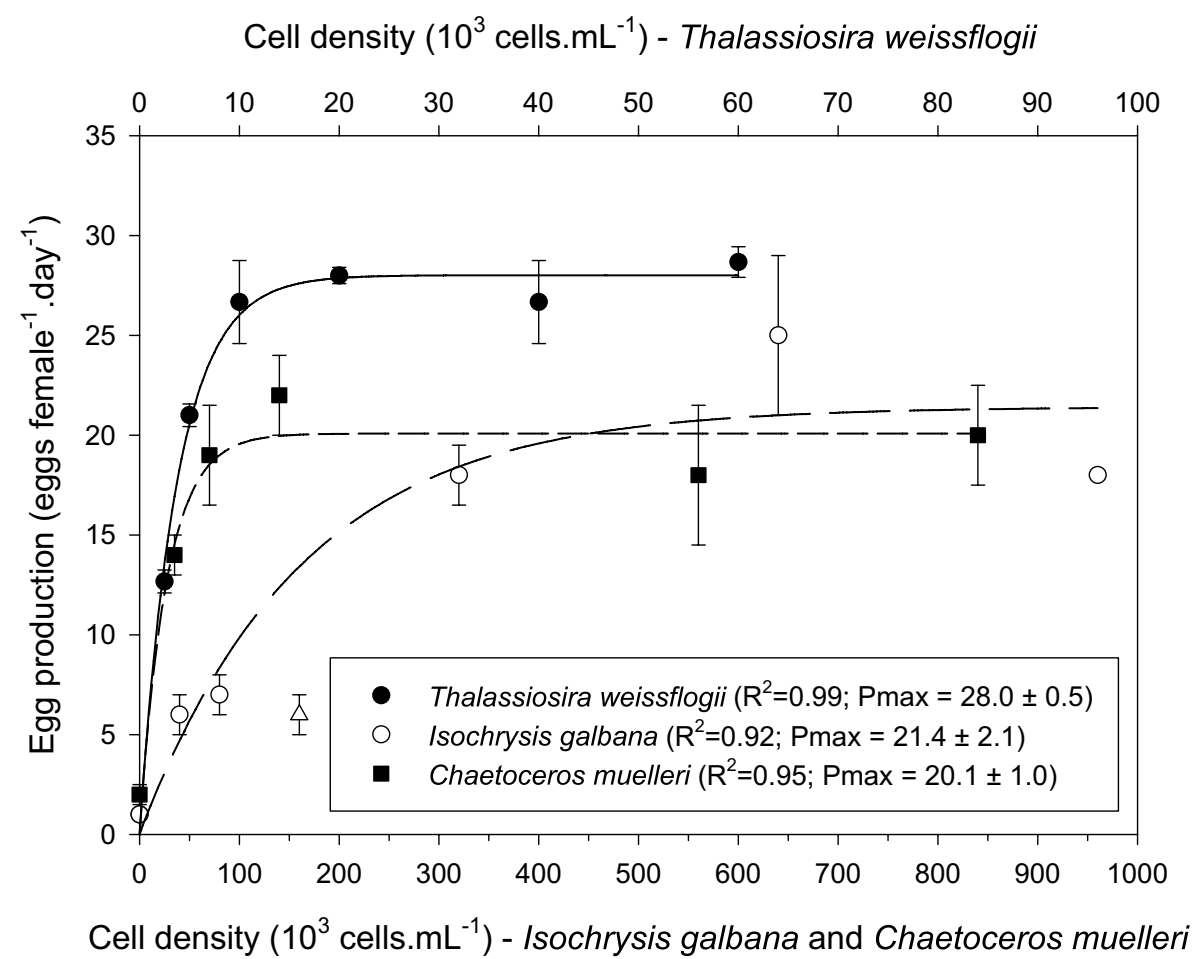

Fig. 1 - Egg production in the copepod Acartia tonsa using three different food sources: the microalgae Thalassiosira weissflogii (closed circles; solid line; top $x$ axis), Chaetoceros muelleri (closed squares; short dashed line; bottom $x$ axis) and Isochrysis galbana (open circles; long dashed line; bottom $x$ axis). Different cell densities were tested for each microalgae species to give an equivalent biovolume value at each experimental condition. Copepods were acclimated to fixed salinity (30), temperature $\left(20^{\circ} \mathrm{C}\right)$ and photoperiod $(12 \mathrm{~L}: 12 \mathrm{D})$ before tests. Tests were performed under the same acclimation conditions. Results are expressed as mean \pm standard error. Data were analyzed by non-linear regression analysis (exponential with saturation). $\mathrm{Pm}=$ maximum egg production expressed as eggs.female ${ }^{-1} \cdot$ day $^{-1} \cdot \mathrm{R}^{2}=$ regression coefficient. Egg production data with I. galbana at $160.10^{3}$ cells.mL ${ }^{-1}$ (open triangle) was considered as an outlier.

was needed. These findings could be explained by the reduced food capture efficiency in $A$. tonsa when particles are between 2 and $4 \mu \mathrm{m}$ (Irigoien et al. 2003, Katechakis et al. 2004). In this context, it is important to emphasize that I. galbana has a smaller size $(\sim 5 \mu \mathrm{m})$ than T. weissflogii $(\sim 13 \mu \mathrm{m})$ and C. muelleri $(5-10 \mu \mathrm{m})$ (Berggreen et al. 1988). According to the size preference for food capture, T. weissflogii shows a more ideal size ( $\sim 13 \mathrm{~mm}$ ) for the adult stage of the copepod A. tonsa (Berggreen et al. 1988). Furthermore, A. tonsa can have low sensitive chemoreception mechanisms (Paffenhofer and Stearns 1988), requiring a higher biomass of smaller algae (e.g. I. galbana) than that of larger ones (e.g. T. weissflogii) (Støttrup and Jensen 1990) to achieve the alimentary response. These facts can explain, at least in part, the highest maximum egg production observed with $T$. weissflogii. It is important to note that the sloppy feeding was not considered when comparing feeding efficiency among the different microalgae tested. According to Møller and Nielsen (2001), A. tonsa does not show sloppy feeding when capturing algae of sizes similar to those employed in the present study ( $\sim 10 \mu \mathrm{m}$ or less).

Ismar et al. (2008) reported that both T. weissflogii and C. muelleri allow the development of all life stages of $A$. tonsa. In the present study, A. tonsa fed on T. weissflogii and C. muelleri reached a saturated egg production at concentrations equivalent in biovolume. However, copepods fed on $T$. weissflogii produced in average $40 \%$ more eggs ( 28 eggs.female ${ }^{-1}$. day ${ }^{-1}$ ) than those fed on C. muelleri (20 eggs.female ${ }^{-1}$.day ${ }^{-1}$ ). Despite the fact that Chaetoceros sp. is a food source for copepods in nature (Uchima 1988, Wu et al. 2004), the 
higher fecundity observed with $T$. weissflogii suggests a preference for use of this microalgae under laboratory conditions. The fact that higher survival rates and better physiological responses and development of various stages of copepods are observed with $T$. weissflogii than with I. galbana under controlled conditions (Tirelli and Mayzaud 2005, Ismar et al. 2008, Koski et al. 2008) also supports this choice.

Despite the fact that a maximum egg production was obtained in the present study with a single food source, especially for $T$. weissflogii, a combination of at least two microalgae species could enhance $A$. tonsa egg production. For example, a higher egg production (32 eggs.female ${ }^{-1}$.day ${ }^{-1}$ ) was obtained in $A$. tonsa fed with a mixture of I. galbana and Rhinomonas reticulata (Medina and Barata 2004) than in those fed only with $I$. galbana (22 eggs.female ${ }^{-1}$.day ${ }^{-1}$ ) at an equivalent biovolume concentration. In other copepod species, better results were also obtained with plurialgal diets (Buttino et al. 2009).

In summary, data reported in the present study indicate that the feeding regime (microalgae species and density) influences egg production in the copepod Acartia tonsa. Differences in egg production with the different feeding regimes tested in the present study were explained considering the different sizes of the microalgae employed to feed the copepods.

\section{RESUMO}

A produção de ovos do copépode Acartia tonsa foi avaliada utilizando diferentes densidades das microalgas Thalassiosira weissflogii, Chaetoceros muelleri e Isochrysis galbana. Machos e fêmeas foram colocados sob condições controladas (salinidade $30,20^{\circ} \mathrm{C}$, fotoperíodo $12 \mathrm{~L}: 12 \mathrm{D}$ ), aclimatados às condições experimentais e mantidos juntos por $24 \mathrm{~h}$ para permitir a copula. As densidades de algas foram equivalentes em biovolume e corresponderam a $0,2,5,5,10,20,40$ e $60,10^{3}$ células. $\mathrm{mL}^{-1}$ de $T$. weissflogii. Dez fêmeas aclimatadas foram separadas, transferidas para frascos de vidro e expostas por mais $24 \mathrm{~h}$ ao meio experimental correspondente. Após este período, os ovos foram fixados e contados. A produção de ovos alcançou um valor limiar quando T. weissflogii, C. muelleri e $I$ galbana foram oferecidas a concentrações de $10,10^{3}, 140,10^{3} \mathrm{e}$ $640,10^{3}$ células. $\mathrm{mL}^{-1}$, respectivamente. A média de produção de ovos correspondeu a $28,0 \pm 0,5,20,1 \pm 1,0$ e $22,0 \pm 3,5$ ovos.fêmea ${ }^{-1} \cdot \mathrm{dia}^{-1}$, respectivamente. Copépodes alimentados com T. weissflogii mostraram a maior produção de ovos média enquanto os alimentados com I. galbana alcançaram uma produção de ovo máxima quando as algas foram providas a uma densidade de duas a quatro vezes maior, considerando o biovolume de $T$. weissflogii e C. muelleri. Estas diferenças podem ser explicadas considerando os diferentes tamanhos das microalgas utilizadas para alimentar os copépodes.

Palavras-chave: produção de ovos, Acartia tonsa, microalgas.

\section{REFERENCES}

Azaiteiro UM, Marques SC, Vieira LMr, PastoRINHo MRD, PEREIRA PAB, RÉ MJ AND Morgado FMR. 2005. Dynamics of the Acartia genus (Calanoida: Copepoda) in a temperate shallow estuary (the Mondego estuary) on the west cost of Portugal. Acta Adriat 46: $7-20$.

Berggreen U, Hansen B And Kiørboe T. 1988. Food size spectra, ingestion and growth of the copepod Acartia tonsa during development: implications for determination of copepod production. Mar Biol 99: 341-352.

Bielmyer GK, Grosel M AND BRIX KV. 2006. Toxicity of silver, zinc, copper, and nickel to the copepod Acartia tonsa exposed via a phytoplankton diet. Environ Sci Technol 40: 2063-2068.

BJÖRNBERG TSK. 1981. Copepoda. In: BoltovsKOY D (Ed), Atlas del zooplancton del Atlantico Sudoccidenteal y Metodos de Trabajos con el Zooplancton Marino. INIDEP, Mar del Plata, Argentina, p. 587-677.

Butler M AND DAM HG. 1994. Production rates and characteristics of fecal pellets of the copepod Acartia tonsa under simulated phytoplankton bloom conditions: implications for vertical fluxes. Mar Ecol Prog Ser 114: 81-91.

Buttino I, IAnora A, Buono S, Vitello V, SAnsone G ANd Miralto A. 2009. Are monoalgal diets inferior to plurialgal diets to maximize cultivation of the calanoid copepod Temora stylifera? Mar Biol 156: 1171-1182.

CARDOzO AP. 2004. Influência de diferentes salinidades na reprodução e crescimento de Acartia tonsa (Copepoda, Calanoida). Disponível em: http://www.pluridoc.com.

CAstro-Longoria E. 2003. Egg Production and hatching success of four Acartia species under different temperature and salinity regimes. J Crust Biol 23: 289-299.

Ceballos S And Ianora A. 2003. Different diatoms induce contrasting effects on the reproductive success of 
the copepod Temora stylifera. J Exp Mar Biol Ecol 294: 189-202.

CHECKLEY DM. 1980. The egg production of a marine planktonic copepod in relation to its food supply: laboratory studies. Limnol Oceanogr 25: 430-446.

Delbare D, Dhert P And LaVens P. 1996. Zooplankton. In: MANual on the Production and Use of Live FoOd FOR AQUACUlTuRE. FAO Fisheries Technical Paper, p. 252-281.

Gaudy R, Cervetto G and Pagano M. 2000. Comparison of the metabolism of Acartia clausi and Acartia tonsa: influence of temperature and salinity. J Exp Mar Biol Ecol 247: 51-65.

GUILlard RRL AND RYTHER JH. 1962. Studies of marine planktonic diatoms Cyclotella nanna (Hustedt) and Detonula convervacea (Cleve). Gran Can J Microbiol 8: 229-239.

Helland S, Terjesen BF and Berg L. 2003. Free amino acid and protein content in the planktonic copepod Temora longicornis compared to Artemia franciscana. Aquaculture 215: 213-228.

Hillebrand H, Dürselen CD, Polingher U And ZoHARY T. 1999. Biovolume calculation for pelagic and benthic microalgae. J Phycol 35: 403-424.

IRIGOIEN X, TITELMAN J AND HARRIS RP. 2003. Feeding of Calanus finmarchicus nauplii in the Irminger Sea. Mar Ecol Prog Ser 262:193-200.

ISMAR MH, HANSEN T AND SOMMER U. 2008. Effect of food concentration and type of diet on Acartia survival and naupliar development. Mar Biol 154: 335-343.

JAKOBSEN HH, HALVORSEN E, HANSEN BW AND VISSER AW. 2005. Effects of prey motility and concentration on feeding in Acartia tonsa and Temora longicornis: the importance of feeding modes. J Plankton Res 27: 775-785.

KAMINSKI SM AND Montú MA. 2005. Produção de ovos dos copépodes costeiros Acartia tonsa, Temora stylifera e Temora turbinata da Praia do Cassino, Rio Grande, RS. Atlântica 27: 103-111.

Katechakis A, Stibor H, Sommer U and Hansen T. 2004. Feeding selectivities and food-niche separation of Acartia clausi, Penilia avirostris (Crustacea) and Doliolum denticulatum (Thaliacea) in Blanes Bay (Catalan Sea, NW Mediterranean). J Plankton Res 26: 589-603.

Kiørboe T, Mohlenberg F And Hamburger K. 1985. Bioenergetics of the planktonic copepod Acartia tonsa: relation between feeding, egg production and respiration, and composition of specific dynamic action. Mar Ecol Prog Ser 26: 85-97.

KLEPPEL GS. 1992. Environmental regulation of feeding and egg production by Acartia tonsa off southern California. Mar Biol 112: 57-65.

KLeppel GS And HazZard SE. 2000 Diet and egg production of the copepod Acartia tonsa in Florida Bay. II. Role of the nutritional environment. Mar Biol 137: 111-121.

Kleppel GS, Burkart CA, Houchin L and Tomas C. 1998. Egg production of the copepod Acartia tonsa in Florida Bay during Summer. 1. The roles of food environment and diet. Estuaries 21: 328-339.

Koski M, Wichard T AND JÓNASDÓtTiR SH. 2008. "Good" and "bad" diatoms: development, growth and juvenile mortality of the copepod Temora longicornis on diatom diets. Mar Biol 154: 719-734.

Kraul S, Nelson A, Brittain K, Ako H and OgaSAWARA A. 1992. Evaluation of live feeds for larval and postlarval mahimahi Coryphaena hippurus. J World Aquacult Soc 23: 299-307.

Leandro SM, Morgado F, Pereira F AND QueIroga H. 2007. Temporal changes of abundance, biomass and production of copepod community in a shallow temperate estuary (Ria de Aveiro, Portugal). Est Coast Shelf Sci 74: 215-222.

Mauchline J. 1998. The Biology of Calanoid Copepods. Advances in Marine Biology. London, Academic Press, $710 \mathrm{p}$.

McKinnon AD, Duggana S, Nichols PD, Rimmer MA, SEMmens G And Robino B. 2003. The potential of tropical paracalanid copepods as live feeds in aquaculture. Aquaculture 223: 89-106.

Medina M AND BARATA C. 2004. Static-renewal culture of Acartia tonsa (Copepoda: Calanoida) for ecotoxicological testing. Aquaculture 229: 203-213.

Møller EF AND Nielsen TG. 2001. Production of bacterial substrate by marine copepods: effect of phytoplankton biomass and cell size. J Plankton Res 23: 527-536.

Paffenhofer GA And Stearns DE. 1988. Why is Acartia tonsa (Copepoda: Calonoida) restricted to nearshore environments? Mar Ecol Prog Ser 42: 33-38.

Pedroso MS, Bersano JG And Bianchini A. 2007. Acute silver toxicity in the euryhaline copepod Acartia tonsa: influence of salinity and food. Environ Toxicol Chem 26: 2158-2165. 
Pinho GLL, Pedroso MS, Rodrigues SC, Souza SS AND Bianchini A. 2007. Physiological effects of copper in the euryhaline copepod Acartia tonsa: waterborne versus waterborne plus dietborne exposure. Aquat Toxicol 84: $62-70$.

RichaRdSON AJ AND VERHEYE HM. 1998. The relative importance of food and temperature to copepod egg production and somatic growth in the southern Benguela upwelling system. J Plankton Res 20: 2379-2399.

Saiz E, Calbet A, Atienza D and Alcaraz M. 2007. Feeding and production of zooplankton in the Catalan Sea (NW Mediterranean). Progr Oceanog 74: 313-328.

SARGEnt JR, MCEvoy LA AND Bell JG. 1997. Requirements, presentation and sources of polyunsaturated fatty acids in marine larval feeds. Aquaculture 155: 117-127.

Schipp GR, Bosmans JMP AND Marshall AJ. 1999. A method for hatchery culture of tropical calanoid copepods, Acartia spp. Aquaculture 174: 81-88.

StøтtRUP JG. 2000. The elusive copepods: their production and suitability in marine aquaculture. Aquacult Res 31: 703-711.
StØtTRUP JG AND JENSEN J. 1990. Influence of algal diet on feeding and egg-production of the calanoid copepod Acartia tonsa Dana. J Exp Mar Biol Ecol 141: 87-105.

Støttrup JG AND Nosker NH. 1997. Production and use of copepods in marine fish larviculture. Aquaculture 155: 231-247.

Tirelli V AND Mayzaud P. 2005. Relationship between functional response and gut transit time in the calanoid copepod Acartia clausi: role of food quantity and quality. J Plankton Res 27: 557-568.

UCHIMA M. 1988. Gut content analysis of neritic copepods Acartia omorii and Oithona davisae by a new method. Mar Ecol Prog Ser 48: 93-97.

Watanabe T, Katajima C and Fujita S. 1983. Nutritional value of live organisms used in Japan for mass propagation of fish: a review. Aquaculture 34: 115-143.

Wu CH, HWANG JS AND YANG JS. 2004. Diets of three copepods (Poecilostomatoida) in the Southern Taiwan Strait Zool Stud 43: 388-392. 